\title{
Light-Stimulated Polysaccharide and Protein Synthesis by Synchronized, Single Generations of Blastocladiella emersonii
}

\author{
By A. GOLDSTEIN AND E. C. CANTINO \\ Department of Botany and Plant Pathology, Michigan State University, \\ East Lansing, Michigan, U.S.A.
}

(Received 21 November 1961)

\begin{abstract}
SUMMARY
Improved methods are described for growing about $10^{8}$ to $10^{9}$ synchronized single generations of ordinary-colourless (OC) cells of the aquatic fungus Blastocladiella emersonii in submerged liquid $1200 \mathrm{ml}$. cultures at $24^{\circ}$. The stimulatory effect of white light on the synthesis of the internal pool of soluble protein and soluble polysaccharide, and on the dry wt./cell during ontogeny was assessed. Soluble protein was characterized by fractionation on DEAE-cellulose into a number of components: the quantities/cell were affected differentially by illumination. Light caused a sharp decrease in total glucose-6-phosphate dehydrogenase activity/cell during the last stages of growth, when the light-induced formation of soluble polysaccharide/cell was most pronounced.
\end{abstract}

\section{INTRODUCTION}

An ordinary-colourless (OC) plant of the aquatic phycomycete Blastocladiella emersonii (Cantino \& Hyatt, 1953) begins its life history as a uninucleate uniflagellate spore. After a swimming stage, the flagellum is retracted, the single nucleus divides, and the cell begins to enlarge. Successive nuclear divisions and a gradual increase in size culminate in the formation of a two-celled plant. The prominent terminal cell is globose and contains hundreds of nuclei. Each nucleus becomes surrounded by a membrane, and the uninucleate units of protoplasm thus formed are subsequently liberated from the parent cell as uniflagellate spores; from these, a second generation is begun. The small subterminal cell (which bears the rhizoids) is delimited by a septum during ontogeny. Its shape and size is greatly affected by environmental conditions and in our cultures is so decreased in size that it becomes almost invisible; in any event, it is essentially devoid of contents. Thus, it is justifiable to consider the development of $B$. emersonii in terms of the growth and differentiation of a single cell (Cantino, 1961).

A population of swimming spores when placed in a liquid medium grow into mature blastocladiellas. These first-generation $\mathrm{OC}$ cells discharge spores which develop into second-generation cells, and these, in turn, produce a third, a fourth, etc., generation in similar fashion. About 6 years ago an interesting phenomenon involving such 'multiple' generation cultures was discovered (Cantino \& Horenstein, 1956); they yielded much more dry weight when grown in the light than when grown in the dark. Subsequently, but again with multiple generation cultures, it 
was found (Cantino \& Horenstein, 1956; Cantino, 1959) that: $(a)$ white light induced the organism to consume glucose and $\mathrm{CO}_{2}$ more rapidly; $(b)$ the degree of light stimulation was affected by the concentration of exogenous glucose; $(c)$ the relative quantities of $\mathrm{CO}_{2}$-fixation products, nitrogenous constituents, and sulphur-containing compounds in the cell were altered by exposure of the organism to light. Later, with populations grown for only one generation, it was found that light accelerated the rate of reproduction of nuclei and the synthesis of deoxyribonucleic acid (DNA; Turian \& Cantino, 1959) in young cells, that it depressed the rate of glycine uptake by such cells (Cantino \& Turian, 1961), and that the'latter phenomenon required exogenous $\mathrm{CO}_{2}$. With older cells, light accelerated uptake of glycine, incorporation of labelled carbon from glycine-2-14 $\mathrm{C}$ into DNA, and net synthesis of DNA/cell (Cantino \& Turian, 1961). Also illumination extended the generation time of the cell (provided $\mathrm{CO}_{2}$ was present). The effective wavelengths were in the blue end of the spectrum, and the requirement for light could be by-passed by providing the cells with equimolar quantities of exogenous succinate and glyoxylate (Cantino \& Horenstein, 1959). These observations, particularly those dealing with glycine uptake, made it clear that the qualitative and quantitative expressions of the light effect in Blastocladiella emersonii depended on the age of the cell. We devised a means of growing the organism so that it could be examined at all stages in its development-i.e. synchronized single-generation cultures. With such cultures certain aspects of enzyme synthesis during ontogeny have already been established (McCurdy \& Cantino, 1960; Lovett \& Cantino, 1960, 1961; Cantino, 1961). For OC cells in particular, this technique has now been refined to a point where, in spite of their extensive system of tapering rhizoids, up to $10^{9}$ cells $/ 1200 \mathrm{ml}$. of medium are made to develop un-entangled and evenly distributed in submerged liquid culture as individuals of uniform dimensions. Even the light-induced extended generation time, exhibited by plants grown on solid media (Cantino \& Horenstein, 1959), is reproduced in liquid culture. With these cultures, we have begun to examine the quantitative and qualitative aspects of 'lumisynthesis' (light-induced increase in dry wt. of a micro-organism devoid of chlorophyll; McCurdy \& Cantino, 1960) in B. emersonii; some results are here reported.

\section{METHODS}

Culture methods. Uniform spore inocula were obtained by flooding with water $14 \mathrm{~cm}$. diam. Petri plates of Difco PYG agar bearing thousands of mature OC plants on the agar surface (McCurdy \& Cantino, 1960). The resulting suspension of swimming spores was filtered through filter paper (No. 500; E. H. Sargent Co., Chicago, Illinois, U.S.A.) to remove mature cells dislodged from the agar; it generally contained $5 \times 10^{5}$ to $5 \times 10^{6}$ spores $/ \mathrm{ml}$. Population densities of spore inocula were estimated turbidimetrically $\left(10^{5}\right.$ cells $/ \mathrm{ml} .=$ optical density (OD) of 1.0 units on a Klett-Summerson colorimeter with a $420 \mathrm{~m} \mu$ filter). The viable spore count was also always determined accurately by transferring measured samples of the suspension to plates of PYG medium at $22^{\circ}$, and counting the number of mature 1st generation plants produced.

We support the pleas (e.g. Herbert, 1961) for the use of chemically defined media in studies of micro-organisms. However, the defined medium (Barner \& 
Cantino, 1952) at present available, while adequate for propagating multiplegeneration cultures, is not suitable for single-generation cultures. Therefore, Difco PYG broth was used for growing such cultures; while not a chemically defined medium, it supports vigorous growth and a reproducible pattern of development. Media $\left(6 \cdot 6 \mathrm{~g}\right.$. PYG/1200 ml. $5 \times 10^{-3} \mathrm{M}$-phosphate buffer, $\mathrm{pH} \mathrm{6.7)}$ were dispensed in 2 l. Erlenmeyer flasks fitted with two aeration tubes, autoclaved $\left(35 \mathrm{~min} ., 120^{\circ}\right)$, inoculated with spores (final conc., $10^{7}$ to $3 \times 10^{8}$ spores/flask), placed in a water bath $\left(24^{\circ} \pm \mathbf{0} \cdot 05^{\circ}\right)$ and aerated vigorously (about $5 \mathrm{l}$. air/min.). Cultures were either illuminated from below with fluorescent ('cool white'; KEN-RAD brand, U.S.A.) bulbs, yielding $\mathbf{5 0 0}$ f.c. at the bottom surface of the vessels, or they were kept dark by covering with aluminium foil. They were sampled at intervals for size measurements and photography (Leitz Ortholux, Kodak Panatomic X). Populations were harvested on filter paper with suction and washed with about $500 \mathrm{ml}$. water/g. wet wt. organism, care being taken to keep the cells wet throughout the procedure. Finally, surface water was removed by vacuum filtration, the cells sucked for about 5 min., and then frozen. The generation time of a population was defined as that time at which $5 \%$ of the cells had produced discharge papillae.

Analytical methods. Known numbers of cells were disrupted in glass homogenizers (about $1 \mathrm{~g}$. wet wt. organism $/ 2 \mathrm{ml}$. water) at about $0^{\circ}$ for $10 \mathrm{~min}$. Samples of the whole homogenate were dried to constant weight at $75^{\circ}$ in vacuo, and the dry wt./ cell thus found. Other samples were centrifuged at $16,000 \mathrm{~g}\left(5 \mathrm{~min} ., 2-4^{\circ}\right)$ when trichloroacetic acid (TCA) extractions for polysaccharide studies (see later) were to be involved, and at $22,000 \mathrm{~g}\left(20 \mathrm{~min} ., 1^{\circ}\right)$ for all other work. The latter supernatant fluids were dialysed for $20 \mathrm{hr}$., with one change, against $500 \mathrm{ml} .10^{-2} \mathrm{M}$-' TrisHCl' buffer, pH 7•4.

The approximate nucleic acid content was estimated from 260 and $280 \mathrm{~m} \mu$ absorption data, by using a Beckman DU spectrophotometer (method of Warburg and Christian; Layne, 1957).

Soluble protein assays were made turbidimetrically with TCA (Stadtman, Novelli $\&$ Lipman, 1951) on dialysed supernatant fluids.

The dialysed protein pool was further fractionated on DEAE-cellulose (Eastman; Distillation Products Ind., Rochester, N.Y., U.S.A.). After removing fines by repeated suspension in water and decantation, the DEAE-cellulose was washed successively with acetone, acetone plus water $(1+1$ by vol.), $\mathrm{M}-\mathrm{NaCl}$, and water, and transferred to a water-jacketed tube (coolant, $10^{\circ}$ ) to yield a column of DEAEcellulose $(1 \mathrm{~cm}$. diam. $\times 12 \mathrm{~cm}$. high) placed over an automatic fraction collector (Rinco Instr. Co., Greenville, Ill., U.S.A.). Protein solutions (generally 5-15 ml.) were fed to the column (protected by a glass-wool plug) by gravity flow, followed by $16 \mathrm{ml}$. of $0.005 \mathrm{M}-\mathrm{NaCl}$. An additional $34 \mathrm{ml}$. of $0.005 \mathrm{M}-\mathrm{NaCl}$ were placed in a $50 \mathrm{ml}$. reservoir, arranged at the top of the chromatography tube so'that the solvent fell dropwise (about $1.7 \mathrm{ml} . / \mathrm{min}$.) on to the $10 \mathrm{ml}$. head of liquid above the DEAEcellulose at the same rate as fluid left the column. Once the $0.005 \mathrm{M}-\mathrm{NaCl}$ in the $50 \mathrm{ml}$. reservoir was exhausted, $50 \mathrm{ml}$. of $0.0055 \mathrm{M}-\mathrm{NaCl}$ were introduced. This in turn was replaced in succession by $50 \mathrm{ml}$. of each of the following $\mathrm{NaCl}$ solutions (м): $0.007,0.01,0.035,0.05,0.065,0.09,0.125,0.175,0.4,0.5,0.65$, and 1.0 . Thus, the $10 \mathrm{ml}$. liquid head over the DEAE-cellulose was maintained throughout the procedure, and it served to introduce an element of gradient elution into an other- 
wise essentially step-wise procedure. This empirical approach was selected after repeated attempts with direct gradient elution and other step-wise procedures failed to yield satisfactory results. The fractionation patterns were highly reproducible, and even the smallest peaks (e.g. as in Fig. 6) were repeatedly obtained. Protein in the fractions was estimated from absorption data at 260 and $280 \mathrm{~m} \mu$ (Layne, 1957).

Blastocladiella polysaccharide. The isolation of polysaccharide (modified to include two successive TCA extractions), its hydrolysis (cf. Hassid \& Abraham, 1957), and its assay with glucose oxidase ('Glucostat' reagent of Worthington Biochem. Corp., Freehold, N.J., U.S.A.) have been described (Cantino \& Goldstein, 1961). Methods for its purification have been improved by a slight modification. After the initial extraction and precipitation of polysaccharide, care was used in removing TCA-insoluble contaminants which precipitate with the polysaccharide. The polysaccharide was redissolved in water and centrifuged $(1600 \mathrm{~g})$, the supernatant fluid brought to $5 \%$ TCA, and the polysaccharide reprecipitated with an equal volume of $95 \%$ ethanol; this process was repeated. The polysaccharide was washed successively with 48, 95 and $100 \%$ ethanol, followed by two extractions with diethyl ether. The resulting product yielded about $98 \%$ glucose on hydrolysis.

Glucose-6-phosphate dehydrogenase. The dialysed supernatant fluids remaining after centrifugation at $22,000 \mathrm{~g}$ were used. Reaction mixtures contained: about $0.2 \mathrm{mg}$. protein, $20 \mu$ mole $\mathrm{MgCl}_{2}, 30 \mu$ mole 'Tris-HCl' buffer, $\mathrm{pH} 7 \cdot 4,30 \mu$ mole glucose-6-phosphate, $\mathbf{0 . 6} \mu$ mole triphosphopyridine nucleotide, and water to $3 \cdot 0 \mathrm{ml}$. After addition of enzyme, the change in OD at $340 \mathrm{~m} \mu$ was followed for $10 \mathrm{~min}$., during which time the rates were linear. Endogenous activity was essentially zero.

\section{RESULTS}

\section{Growth patterns for synchronized cultures}

Synchronized OC cells at different stages in development are shown in Pl. 1. Note the point of attachment of rhizoids; the second basal cell to which rhizoids are usually attached when Blastocladiella emersonii is grown on solid media or on solid substrata submerged in liquid media, is almost non-existent (see Pl. 1, bottom left). The changes in log vol./cell (dark-grown) and log dry wt./cell (light grown) are shown in Figs. 1 and 2. The growth pattern appears to be essentially exponential; the reason for the break in the dry wt. curve at $70 \%$ of the generation time remains to be clarified.

\section{Effects of illumination on cellular constituents}

In PYG liquid medium at $\mathbf{2 4}^{\circ}$, the generation time of a dark-grown cell was $16 \mathrm{hr}$; for a light-grown cell, $\mathbf{1 7 . 5} \mathrm{hr}$. To facilitate comparisons and interpretations of the effect of light, the parameters associated with growth have been related to the generation time of the cell.

Dry rot./cell. The increase in dry wt./cell was greater in the light than in the dark; it became most readily detectable once the cell had progressed beyond $40 \%$ of its generation time. At maturity, the final dry wt./light-grown cell was about $51 \%$ greater than that for a dark-grown cell (Fig. 3).

Nucleic acid/cell. The nucleic acid in the dialysed supernatant fluid fraction after 
centrifugation at $22,000 \mathrm{~g}$ increased more rapidly in the light than in the dark and the final quantity in a mature light-grown cell was $28 \%$ higher than that in a darkgrown cell (Fig. 4).

Soluble protein/cell. The protein found in dialysed supernatant fluid after centrifugation at $22,000 \mathrm{~g}$ was also greatly increased by exposure of the cell to illumination (Fig. 5); the final soluble protein/mature light-grown cell was about $37 \%$ greater than that of its dark-grown counterpart. Fractionation of this protein pool on DEAE-cellulose (Fig. 6) revealed over twenty components; even the minor ones were detectable with great reproducibility.

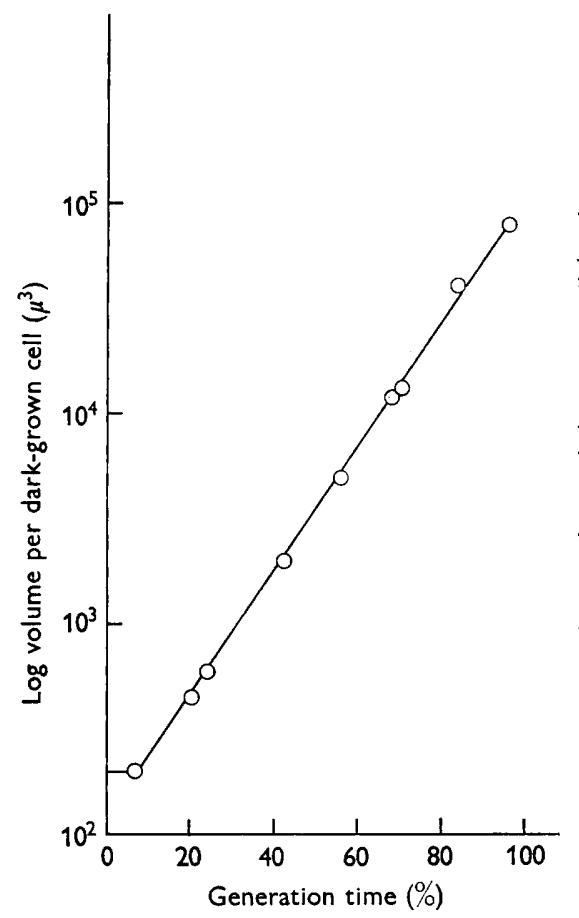

Fig. 1

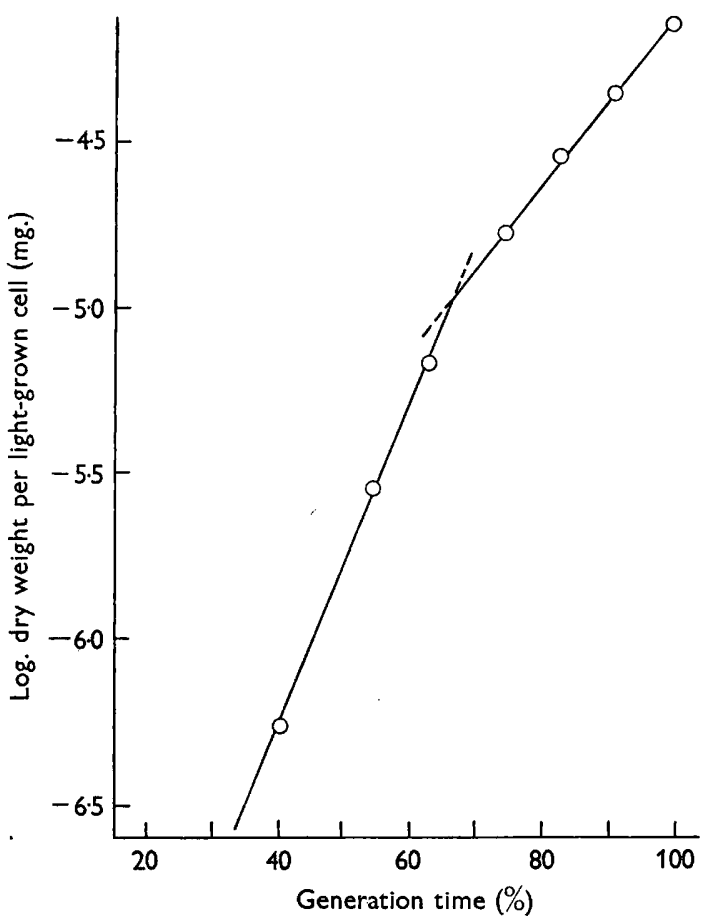

Fig. 2

Fig. 1. The log-vol./OC cell during growth in the dark, medium PYG, 24. Note lag of about $1 \frac{1}{2} \mathrm{hr}$.; it results from a pre-germination swimming stage for the spores.

Fig. 2. The log-dry wt./OC cell during growth in 500 f.c. white light, medium PYG, $24^{\circ}$.

The patterns (Fig. 6) for soluble proteins in mature light-grown and dark-grown cells were similar but not identical. After fractionation the total protein/cell recovered from the light-grown organism was $57 \%$ greater than that recovered from the dark-grown organism (Table 1; note that the increase in total unfractionated protein/cell shown in Fig. 5 is $\mathbf{3 7} \%$; this apparent discrepancy was due to the easily coagulable protein- $\mathbf{P}_{\mathrm{F} 2}$ in footnote, Table 1 - which was not increased by light to the same degree). The overall light-induced increase in fractionated protein appears to be due to the major component in fractions $6,9,9 a$, and 24 , for which the average increase was $48 \%$. However, light also induced differential changes in the minor protein components (Table 1); for example, some fractions (e.g. 11-14, 15-17, 18-19) 


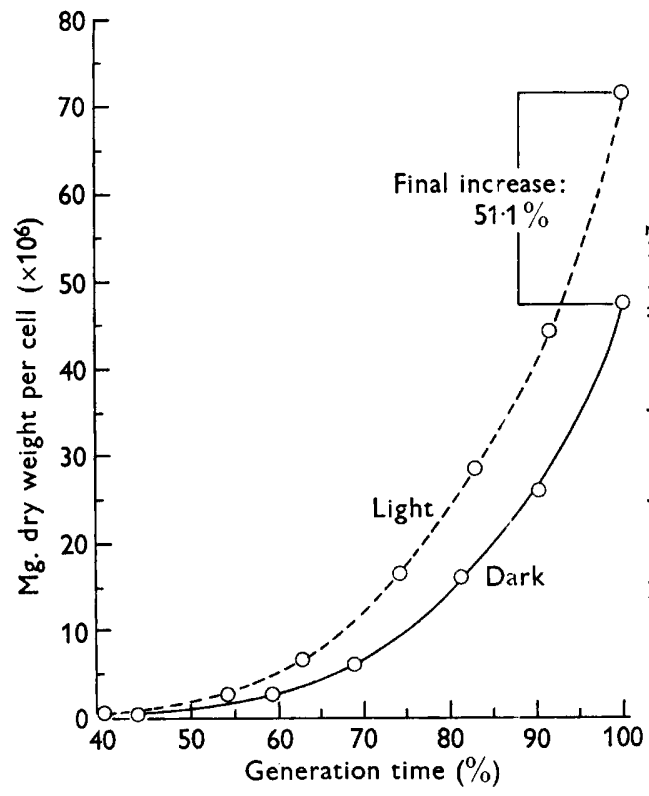

Fig. 3

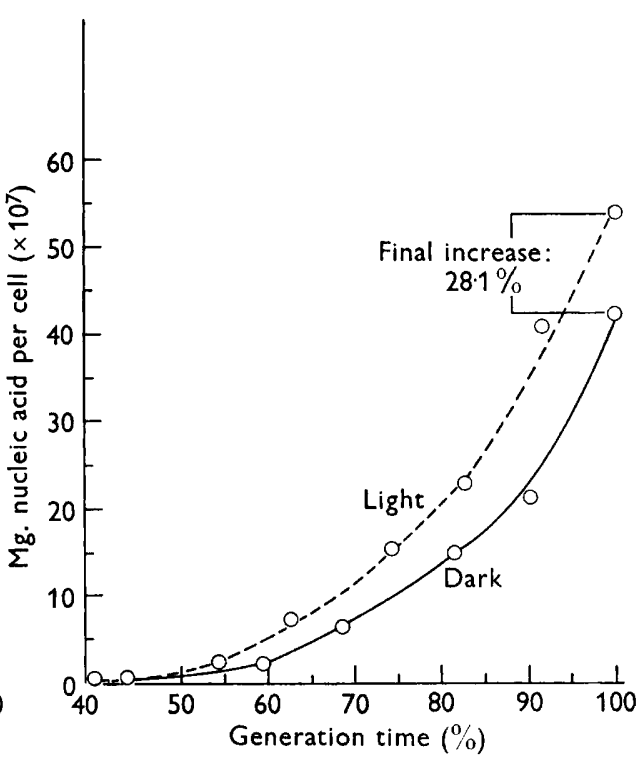

Fig. 4

Fig. 3. The dry-wt./OC cell during growth in the dark and 500 f.c. white light, medium PYG, 24.

Fig. 4. The nucleic acid/OC cell during growth in the dark and 500 f.c. white light, medium PYG, 24․

Table 1. Protein fractions recovered after $D E A E$-cellulose fractionations from lightand dark-grown ordinary-colourless $(O C)$ cells of Blastocladiella emersonii

$\begin{array}{cccc}\begin{array}{c}\text { Protein } \\ \text { fraction }\end{array} & \begin{array}{c}\text { Organisms } \\ \text { light-grown }\end{array} & \begin{array}{c}\text { Organisms } \\ \text { dark-grown }\end{array} & \begin{array}{c}\% \text { increase } \\ \text { in light }\end{array}\end{array}$
mg./cell at generation time $\left(\times 10^{8}\right)$

6
$9-9 a$
$11-14$
$15-17$
$18-19$
$21-22$
24

Total protein recovered $\left(=\mathbf{P}_{\mathrm{F} 1}\right)$
$93 \cdot 5$

$179 \cdot 0$

$23 \cdot 3$

$19 \cdot 6$

$32 \cdot 7$

$39 \cdot 2$

About 100

$726 \dagger$
$75 \cdot 7$

$463 \dagger$

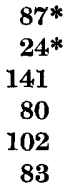

About 32*

* These three major fractions account for over $70 \%$ of the protein recovered $\left(\mathrm{P}_{\mathrm{F1}}\right)$; the average $\%$ increase induced by light for these thrce fractions is $48 \%$, which compares favourably with the overall, light-induced increase (37\%; see Fig. 5) in total soluble protein $\left(=\mathbf{P}_{T}\right)$ from direct analysis before fractionation.

+ The $\mathbf{P}_{\mathrm{F1}}$ represents about $36 \%$ (38.2 and $33.4 \%$ for light-grown and dark-grown cells, respectively) of the $\mathbf{P}_{\mathrm{T}}$ originally present in the $22,000 \mathrm{~g}$ supernatant fluid of the cell. About $60 \%$ of the $\mathbf{P}_{\mathrm{T}}$ occurred in an easily coagulable portion $\left(\mathbf{P}_{\mathrm{F}_{2}}\right)$, removed by a single freezing and thawing of the dialysed supernatant fluid; the rest of it consisted of fraction 1 (see Fig. 6) which was not estimated accurately because of the presence of a large quantity of nucleic acid in the first part of this band. 
increased 141, 80 and $102 \%$, respectively, in the light, whereas others (e.g. fractions 4 and 5 ) changed very little.

Polysaccharide/cell. The stimulatory effect of light was most strikingly displayed by the data on the polysaccharide pool (Fig. 7). In the light, polysaccharide/cell reached a final concentration almost double that in the dark-grown cell.

Glucose-6-phosphate dehydrogenase/cell. The specific activity (see Fig. 8) of this enzyme was lower in the light-grown cells than in dark-grown ones throughout the

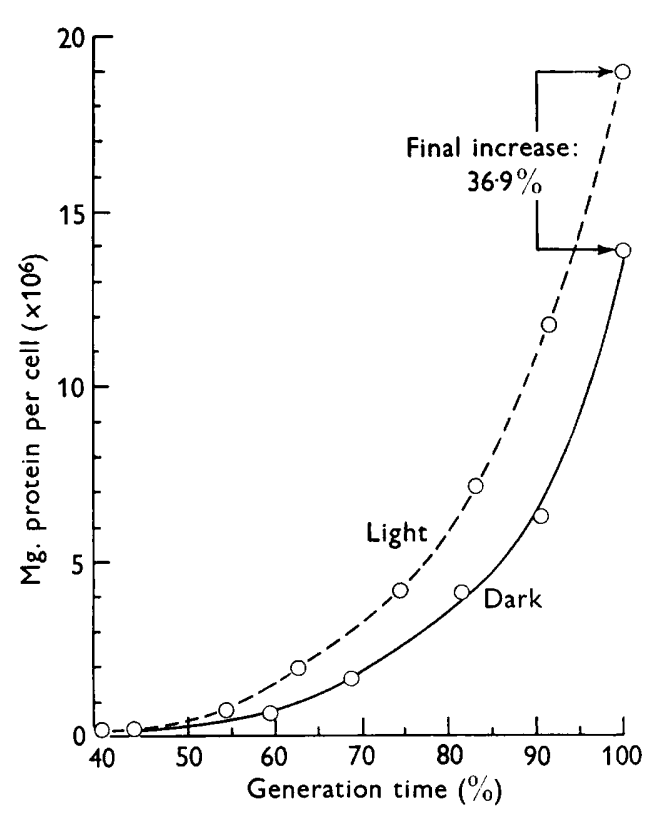

Fig. 5

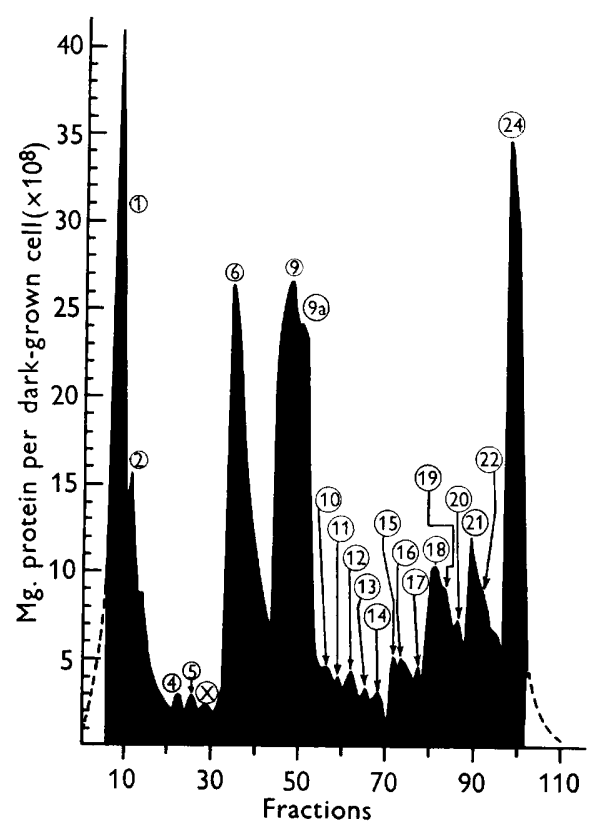

Fig. 6

Fig. 5. The soluble protein/OC cell during growth in the dark and 500 f.c. white light, medium PYG, 24.

Fig. 6. The pattern obtained by fractionating the soluble protein of dark-grown cells on DEAE-cellulose (text for details). Each fraction was $5 \cdot 2 \mathrm{ml}$.

last half of the generation time. But the total units of enzyme/cell was higher in the light-grown cells up to about $80 \%$ of the generation time (Fig. 9); this value then levelled off abruptly while, in the dark, it continued to rise until the cell was mature.

\section{DISCUSSION}

The main purpose of this report was to document the stimulatory effect of light upon gross growth parameters during development of the carotene-free OC cell of Blastocladiella emersonii. With cell populations grown synchronously for one generation, the dry weight, soluble protein, non-sedimentable $(22,000 \mathrm{~g})$ nucleic acid, and soluble polysaccharide per cell increased more rapidly when the organism was exposed to 500 f.c. of white light than when it was grown in the dark; the final increases for mature cells were $51 \cdot 1,36 \cdot 9,28 \cdot 1$ and $73 \cdot 8 \%$, respectively.

Attempts (summarized in Cantino \& Turian, 1961) have been made to integrate 
previous observations on light-stimulated $\mathrm{CO}_{2}$-fixation, glucose uptake, nucleic acid production, glycine uptake, and the need for $\mathrm{CO}_{2}$ in some of these phenomena, into a working hypothesis about the biochemical mechanism for lumisynthesis in Blastocladiella emersonii. Now light-induced synthesis of polysaccharide will also have to be included.

In part because of a peculiar effect of light on the oxidation of glucose-6-phosphate in vitro (Cantino \& Horenstein, 1959), it occurred to us that, in vivo, light might have inhibited a pathway for glucose degradation, thus shunting metabolism toward manufacture of polysaccharide. The fact that the specific activity of glucose6-phosphate dehydrogenase was highest in dark-grown cells (from $\mathbf{5 5} \%$ of their

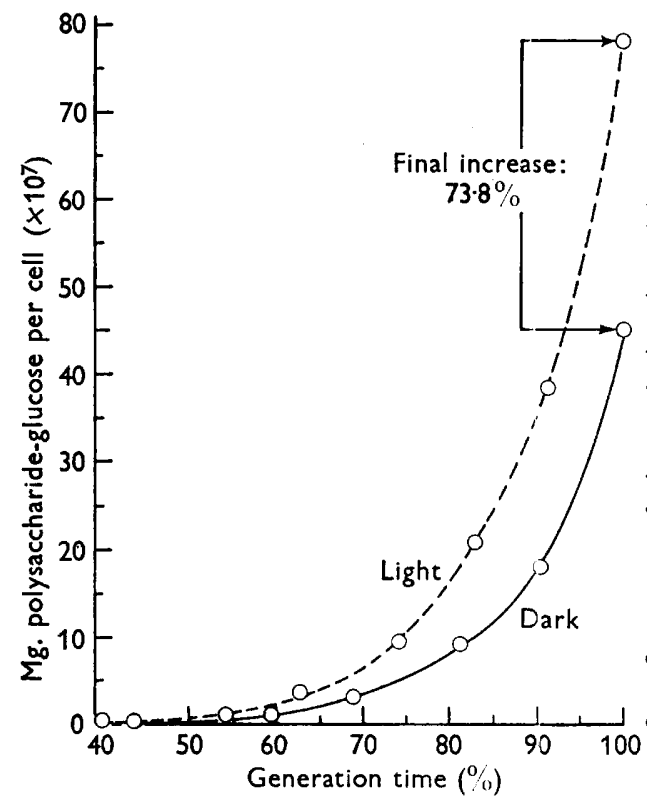

Fig. 7

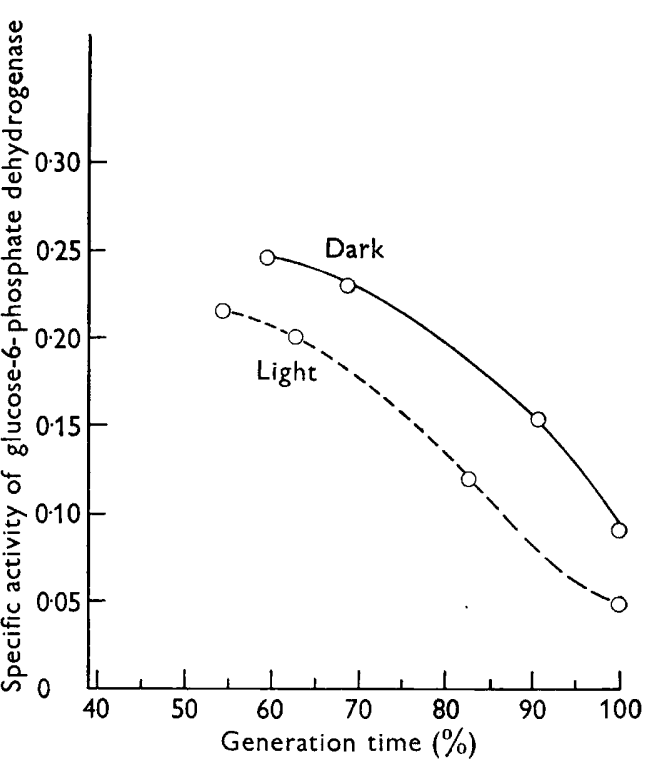

Fig. 8

Fig. 7. The polysaccharide (as polysaccharide-glucose)/OC cell during growth in the dark and 500 f.c. white light, medium PYG, $24^{\circ}$.

Fig. 8. The specific activity (optical density change $\times \min ^{-1} \times \mathrm{mg}^{\text {. protein }}{ }^{-1}$; rates linear in first $10 \mathrm{~min}$.) of glucose-6-phosphate dehydrogenase in $\mathrm{OC}$ cells during growth in the dark and 500 f.c. white light, medium PYG, 24.

generation time to maturity) is consistent with the hypothesis. But when, instead of specific activities, total units of enzyme activity/cell are examined, a different interpretation becomes possible. At $80 \%$ of the generation time, a sharp light effect is suddenly manifest. If the observed degrees of enzyme activity reflect quantities of enzyme protein, then light causes net synthesis of the dehydrogenase to stop at $80 \%$ of the cell's generation time, whereas in the dark synthesis of the enzyme continues until the cell is mature. Thus, as the cell approaches maturity, synthesis of the dehydrogenase and synthesis of polysaccharide appear to be reciprocally related, with cessation of synthesis of an enzyme which carries glucose off along 
an oxidative pathway occurring at that time in the ontogeny of a light-grown cell when net synthesis of polysaccharide becomes most pronounced.

Whatever the ultimate biochemical explanation, however, the light-induced increase in $\mathrm{CO}_{2}$ fixation and polysaccharide production as well as soluble protein and dry weight in an organism devoid of both chlorophyll and coloured carotenoids is noteworthy.

No other studies of the fungi (for example, see summaries compiled by Marsh, Taylor \& Bassler, 1959) have provided evidence for light-induced increases in total

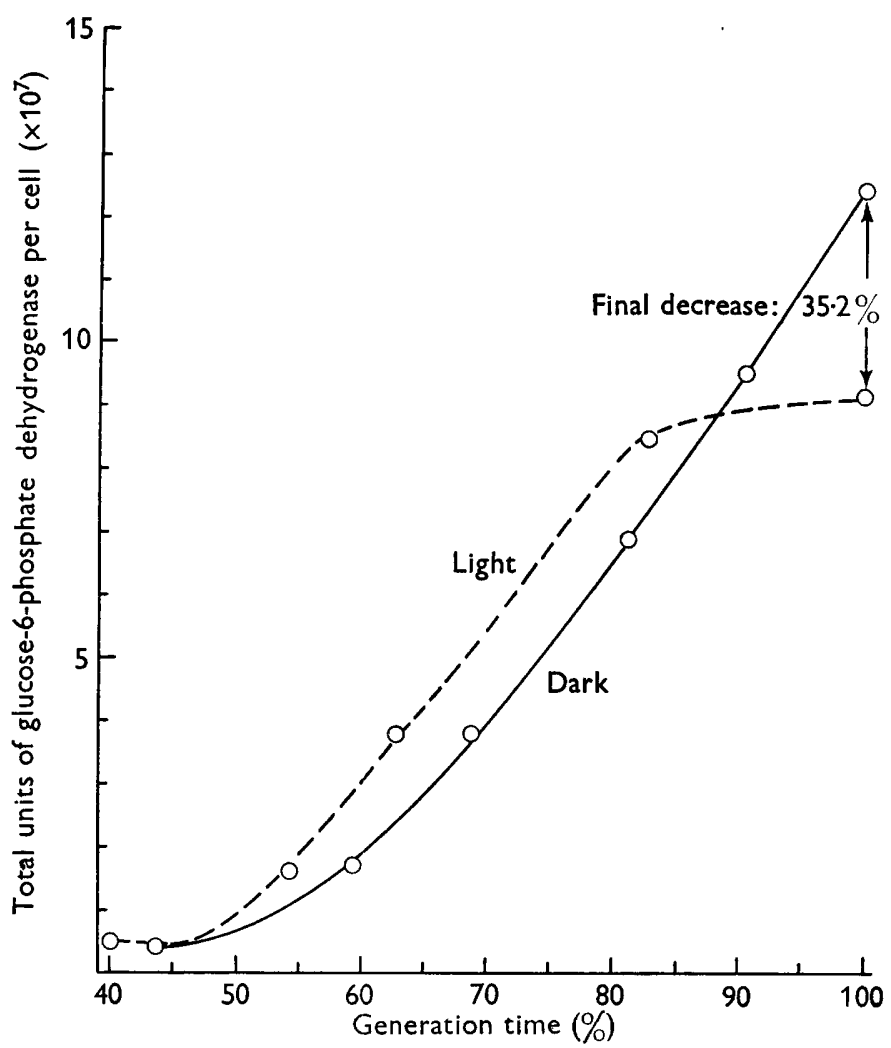

Fig. 9. The total units (specific activity $\times$ mg. protein/cell) of glucose-6-phosphate dehydrogenase/cell during growth in the dark and 500 f.c. white light, medium PYG, $24^{\circ}$.

fungal mass, nor bulk constituents therein. In part this may be because a septate filamentous fungus, by its very nature and because of the usual methods used for its propagation, does not lend itself readily to studies of this kind. A mass of mycelium, started from a few reproductive units and grown for days on solid or in liquid media, is a mixture of cells at many stages of physiological and chronological age. If the end in view is an understanding of the biology of the individual organism itself, then clearly the filamentous fungus is inherently a difficult creature to deal with, and to hurdle the obstacles that it offers will tax the ingenuity of the experimental biologist. Synchronized cultures of a filamentous fungus-albeit even of a 
very small portion of its 'generation time'-would help tremendously to achieve solutions to many problems in mycology now largely unapproachable.

Many non-filamentous aquatic fungi, although they present idiosyncrasies of their own (Emerson, 1950, 1955, 1958; Cantino \& Turian, 1959; Sparrow, 1960; Cantino, 1961), can probably be grown synchronously in reasonably large quantity for a single generation. With Blastocladiella emersonii, heavy inocula of newly formed spores are derived from an immediately preceding and essentially simultaneous division of thousands of multinucleate protoplasts: newly formed cells of the sort obtainable from bacteria, for example, with special selection procedures (Abbo \& Pardee, 1960). Furthermore, synchronized growth does not depend upon an environmental shock, and there seems no question of creating artifacts derived therefrom (e.g. see Williamson \& Scopes, 1961). Because the synchronized Blastocladiella cultures involve only one generation, no complications are introduced by death and lysis. It seems likely that most non-filamentous water fungi can be grown in this fashion.

This work was supported by a U.S. Public Health Service fellowship (GF-14,225) from the Division of General Medical Sciences, Public Health Service, to author A. G., and by research grants from the National Institutes of Health and the National Science Foundation, U.S.A., to author E.C.C.

This is paper no. 61-5 from the Department of Botany and Plant Pathology, Michigan State University, East Lansing, Michigan, U.S.A.

\section{REFERENCES}

Abro, F. E. \& Pardee, A. B. (1960). Synthesis of macromolecules in synchronously dividing bacteria. Biochim. biophys. Acta, 39, 478.

Barner, H. D. \& Cantino, E. C. (1952). Nutritional relationships in a new species of Blastocladiella. Amer. J. Bot. 39, 746.

Cantino, E. C. (1959). Light-stimulated development and phosphorus metabolism in the mold Blastocladiella emersonii. Devel. Biol. 1, 396.

Cantino, E. C. (1961). The relation between biochemical and morphological differentiation in non-filamentous aquatic fungi. Symp. Soc. gen. Microbiol. 11, 243.

Cantino, E. C. \& Goldstein, A. (1961). Bicarbonate-induced synthesis of polysaccharide during morphogenesis by synchronous, single generations of Blactocladiella emersonii. Arch. Mikrobiol. 39, 43.

Cantino, E. C. \& Honenstein, E. A. (1956). The stimulatory effect of light upon growth and $\mathrm{CO}_{2}$ fixation in Blastocladiella. I. Mycologia, 48, 777 .

Cantino, E. C. \& Horenstein, E. A. (1959). The stimulatory effect of light upon growth and $\mathrm{CO}_{2}$ fixation in Blastocladiella. II. Physiol. Plant. 12, 251.

Cantino, E. C. \& Hyatr, M. T. (1953). Phenotypic 'sex' determination in the life history of a new species of Blastocladiella, B. emersonii. Antonie van Leewenhoek J. Microbiol. Serol. 19, 25.

Cantino, E. C. \& Turian, G. F. (1959). Physiology and development of lower fungi (Phycomycetes). Annu. Rev. Microbiol. 13, 97.

Cantino, E. C. \& Turian, G. F. (1961). A role for glycine in light stimulated nucleic acid synthesis by Blastocladiella emersonii. Arch. Mikrobiol. 38, 272.

Emerson, R. (1950). Current trends of experimental research on the aquatic Phycomycetes. Annu. Rev. Microbiol. 4, 169.

Emerson, R. (1955). The biology of water molds. Thirteenth Symposium of the Society for the Study of Development and Growth, p. 171.

Emerson, R. (1958). Mycological organization. Mycologia, 50, 589. 



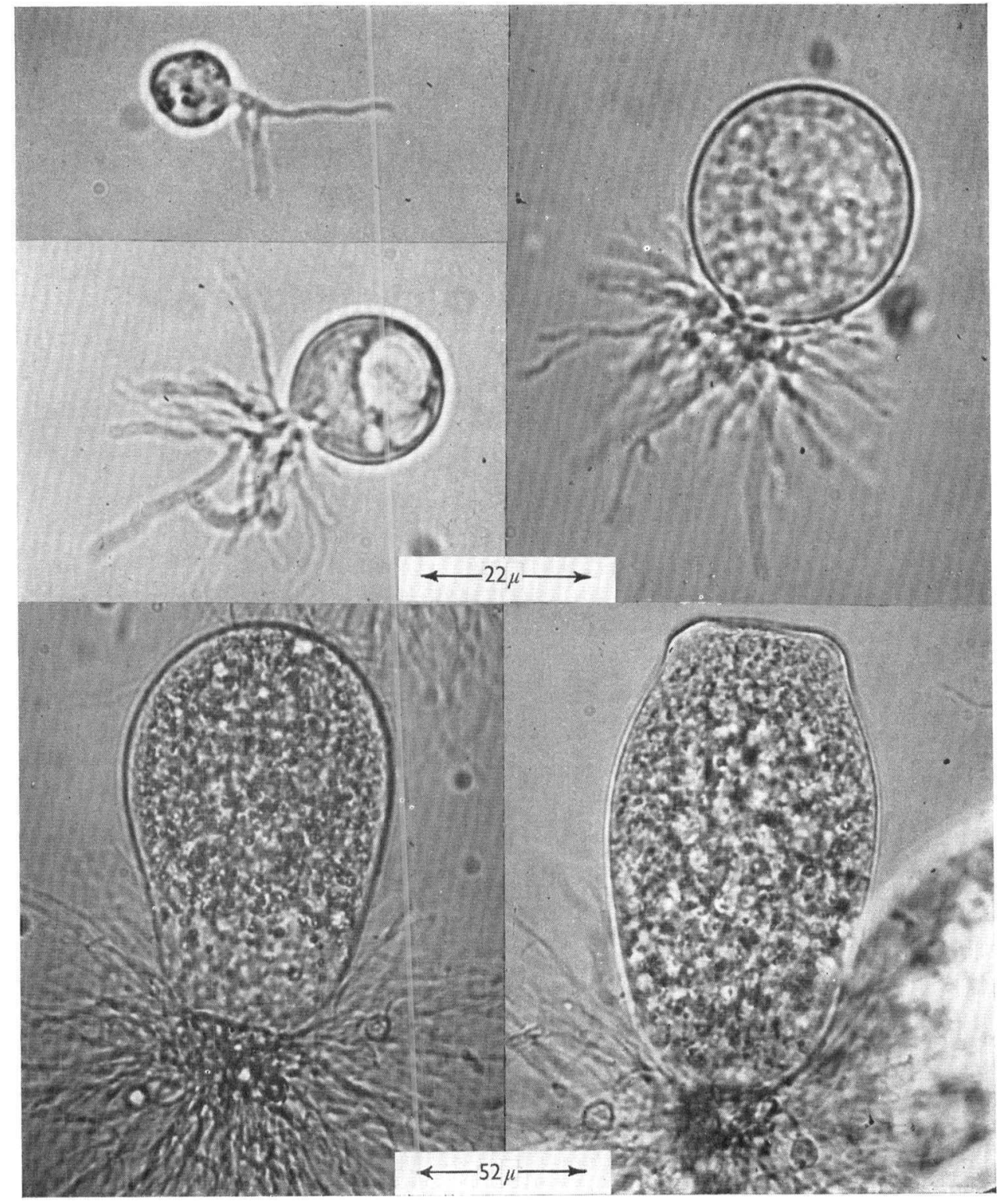


Hassid, W. Z. \& Abraham, S. (1957). Chemical procedures for analysis of polysaccharides. In Methods in Enzymology, ed. S. P. Colowick \& N. O. Kaplan. 3, 34. New York: Academic Press.

Herbert, D. (1961). The chemical composition of micro-organisms as a function of their environment. Symp. Soc. gen. Microbiol. 11, 391.

LAYNE, E. (1957). Spectrophotometric and turbidimetric methods for measuring proteins. In Methods in Enzymology, ed. S. P. Colowick \& N. O. Kaplan, 3, 447. New York: Academic Press.

Lovett, J. S. \& Cantino, E. C. (1960). The relation between biochemical and morphological differentiation in Blastocladiella emersonii. II. Amer. J. Bot. 47, 550.

Lovetr, J. S. \& Cantrno, E. C. (1961). Reversible bicarbonate-induced enzyme activity and the point of no return during morphogenesis in Blastocladiella. J. gen. Microbiol. $24,87$.

Marsh, P. B., TAylor, E. E. \& Bassler, L. M. (1959). A guide to the literature on certain effects of light on fungi: reproduction, morphology, pigmentation, and phototrophic phenomena. Plant Dis. Rep., Suppl. 261, Nov. 15, 1959.

McCurdy, H. D. \& CANTino, E. C. (1960). Isocitritase, glycine-alanine transaminase, and development in Blastocladiella emersonii. Plant Physiol. 35, 463.

Sparrow, F. K. Jun. (1960). Aquatic Phycomycetes, 2nd ed., Univ. of Mich., Ann. Arbor, U.S.A.

Stadtman, E. R., Novelli, G. D. \& Lipmann, F. (1951). Coenzyme A function in and acetyl transfer by phosphotransacetylase system. J. biol. Chem. 191, 365.

Turian, G. \& Cantino, E. C. (1959). The stimulatory effect of light on nucleic acid synthesis in the mold Blastocladiella emersonii. J. gen. Microbiol. 21, 721.

Williamson, D. H. \& Scopes, A. W. (1961). Synchronization of division in cultures of Saccharomyces cerevisiae by control of the environment. Symp. Soc. gen. Microbiol. 11, 217.

\section{EXPLANATION OF PLATE}

The appearance of ordinary-colourless (OC) cells at different stages in their generation time (in 500 f.c. white light, medium PYG, 24. ${ }^{\circ}$. Top: 3,8 and $10 \mathrm{hr}$; ; bottom left and right: 17 and 17.5 hr. The three upper figures are reproduced at $\times 2.3$ magnification of the lower figures. Note the barely visible basal stalk in the nearly mature $17 \mathrm{hr}$. plant, and the newly formed pair of exit papillae in the mature $\mathbf{1 7 \cdot 5} \mathrm{hr}$. plant. 
